Article

\title{
Air Pollution Monitoring in the South-East Baltic Using the Epiphytic Lichen Hypogymnia physodes
}

\author{
Yulia Koroleva * and Vladimir Revunkov \\ Immanuel Kant Baltic Federal University, Kaliningrad 236016, Russia; subjke@mail.ru \\ * Correspondence: yu.koroleff@yandex.ru
}

Received: 16 May 2017; Accepted: 1 July 2017; Published: 3 July 2017

\begin{abstract}
Epiphytic lichens are well-known indicators of air contamination. The chemical composition of lichens is affected by the concentration of pollutants in the environment. Usually, researchers assess long-term variations in trace elements or other pollutants in the study area, or identify spatial features of air contamination. The aim of this study is to create a database of trace element concentrations in the samples of the epiphytic lichen Hypogymnia physodes growing in the Kaliningrad region. The database can be used as a "reference point" for monitoring studies. Another objective is to identify the spatial patterns of iron, manganese, nickel, cadmium, silver, lead, strontium, rubidium, and calcium in the Kaliningrad region. With the help of a regular grid, samples of wild lichens were collected from pine and birch trees, 1.2-1.8 m from their bases, in August 2010. One- to two-year-old thalli were used in the chemical analysis. The metals $\mathrm{Ag}, \mathrm{Cd}, \mathrm{Cu}, \mathrm{Pb}, \mathrm{Ni}, \mathrm{Fe}, \mathrm{Mn}$, and $\mathrm{Zn}$ were determined by atomic absorption spectrometry AAS (Mn and Fe by flame atomic absorption FA AAS and the others by electro thermal atomisation ETA AAS); the elements $\mathrm{Sr}, \mathrm{Rb}$, and $\mathrm{Ca}$ were determined by X-ray fluorescence. The concentration of metals in the western coastal area (the Sambian or Kaliningrad Peninsula) is higher than it is in the central and eastern parts of the region. Principal component factor analysis was carried out to detect and characterise different pollution sources. The authors examined the features of spatial distribution of trace elements. The prevailing wind direction is between south and west; therefore, the highest concentrations of trace elements were found on the Sambian peninsula and on the coasts of the Vistula and Curonian Lagoons. The chemical composition of lichens on the Sambian peninsula may have developed under the impact of both local pollution sources-vehicles, thermal energy facilities, and ports-and such factors as trans-boundary traffic and sea spray.
\end{abstract}

Keywords: air pollution; monitoring; lichen; Hypogymnia physodes; trace elements; south-east Baltic

\section{Introduction}

All living organisms respond to changes in the environment, and lichens are no exception [1-3]. Their sensitivity to atmospheric pollution is explained by their physiological features. Lichens are symbiotic associations of fungi and algae; therefore, any impact can change the balance between them and thus affect lichen viability. Different lichen species can be used to assess environmental contamination [4-6]. The concentration of contaminants in lichens is affected by several factors: the absorption of atmospheric aerosols and gases by the entire surface of thalli and the dehydration of lichen tissues [7-9]. The substrate does not serve as a significant source of metals for lichens. However, this assumption has been questioned in some works [10-13]. There has recently been considerable research devoted to sources of heavy metals, the mechanisms of heavy metal accumulation and detoxification by lichens, and lichen's bioaccumulation capacity [14-20]. The biochemical composition, physiological processes, anatomical and morphological characteristics, population structure, species composition, and structure of lichen communities change under the influence of pollutants [4].

The chemical composition of lichens is affected by the characteristics of their habitat. Thus, epiphytic lichens are used as indicators in air quality monitoring [21-26]. Lichens help to determine 
long-term variations in the level of contamination in the study area, to examine the spatial variability of chemical composition, and to identify the effects of specific pollutants [27-29].

This work aims to create a database of trace element concentrations in the thalli of the lichen Hypogymnia physodes (L.) Nyl. in the south-east Baltic (Kaliningrad region, Russia). Such a database can be used as a "reference point" for monitoring, studying, and investigating trends in the concentration of trace elements in the Kaliningrad region.

\section{Methods}

\subsection{Sampling Sites}

The Kaliningrad region is the Russia's westernmost territory situated on the southeastern coast of the Baltic Sea. The region borders Poland in the south and Lithuania in the north and the east. Westerly winds and marine aerosols of the Baltic Sea dominate the climate in the region [30] and determine the atmospheric transport and deposition of trace elements.

Forests cover only $17 \%$ of the region's territory. These are secondary forests, predominantly mixed coniferous-deciduous ones [31]. Most large forested areas are located in the southeastern and southwestern parts of the region.

There are no large industries in the region with the exception of agriculture and some mining, the latter producing amber, peat, and oil. The western part of the region is highly urbanised, whereas the coastal part of the Kaliningrad (Sambian) peninsula is home to numerous resorts. The level of human impact decreases from west to east. The east of the region is exploited for agriculture.

\subsection{Sampling Procedure and the Method of Analysis}

The epiphytic lichen H. physodes was chosen as a bio-indicator of air contaminant deposition in the Kaliningrad region. The lichen is widely distributed and resistant to impurities in the air-thus, it has been commonly used in regional studies on heavy metal deposition [32-35].

With the use of existing monitoring grid, samples of the lichen $H$. physodes were collected from 54 forest plots measuring $50 \times 50 \mathrm{~m}$ (Figure 1). This grid has been employed since 1999 to monitor trace elements in the atmospheric transport and deposition [36-38]. Sampling points should be located at sites representative of non-urban areas, at least $300 \mathrm{~m}$ from main roads, villages and industries, and at least $100 \mathrm{~m}$ away from smaller roads and houses [39]. Samples were taken from birch and pine trunks, $1.20-1.80 \mathrm{~m}$ from the bases of the trees, in 2010. The sampling period was very short-it did not exceed two weeks. GPS was used to mark the sample plot location. The sampling rules were as follows: $3-5$ samples of lichens were taken from one plot (from 3 to 5 trees), the youngest part (edge) of the lichen thallus was cut, and the samples of lichen were packed in a paper bag.

The unwashed one- and two-year-old lichen thalli were used in analysis after being freed from extraneous materials such as tree bark. The samples were dried to constant weight at $40^{\circ} \mathrm{C}$ for $24 \mathrm{~h}$ and later homogenised. A wet digestion of the homogeneous sub-sample was carried out. A sample preparation method was developed. LabTech DigiBlock digester (LabTech, Sorisole, Italy) was used to digest the samples. About $0.5 \mathrm{~g}$ of lichen was transferred to tubes, and $7 \mathrm{~mL}$ of nitric acid were added. Open tubes were left at room temperature for $12 \mathrm{~h}$, then the temperature was increased to $135^{\circ} \mathrm{C}$ for $15 \mathrm{~min}$, and the samples were digested for $15 \mathrm{~min}$ at $135^{\circ} \mathrm{C}$. After that, the solutions were cooled, $2 \mathrm{~mL}$ of hydrogen peroxide were added, and the temperature was increased to $190{ }^{\circ} \mathrm{C}$. As the volume of acid decreased, the solution became lighter in colour. The obtained mass was transferred to $25 \mathrm{~mL}$ volumetric flasks and filled to mark with osmosis treated water. For X-ray fluorescence analysis, the samples of lichens were dried and pressed. 


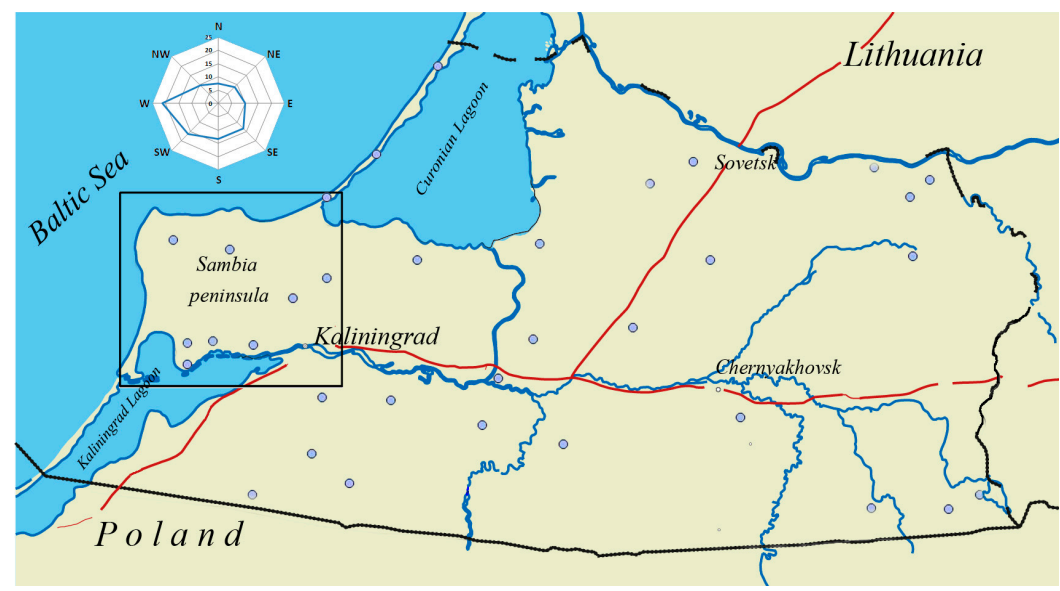

Figure 1. Monitoring grid.

The analysis was carried out with the help of a ContrAA 700 (Analytik Jena, Jena, Germany) atomic absorption spectrometer equipped with xenon lamp. The concentrations of Fe and Mn were determined by flame atomic absorption FA AAS (atomic absorption spectrometry), and $\mathrm{Ag}, \mathrm{Cd}, \mathrm{Cu}$, $\mathrm{Pb}, \mathrm{Ni}$, and $\mathrm{Zn}$ by electro thermal atomisation ETA AAS. X-ray fluorescence spectrometry Spectroscan Max G (Spectron, Sankt Petersburg, Russia) was applied to determine the concentration of $\mathrm{Sr}$, Rb, and $\mathrm{Ca}$. The instrumental parameters were adjusted according to the manufacturer's recommendations.

\subsection{Quality Control}

The quality control of the sample preparation and atomic absorption spectrometry AAS and X-ray fluorescence results was ensured through the use of reference samples (the Canadian waterweed CW-1, SSS 8921-2007 and the birch leaf LB-1, SSS 8921-2007, A.P. Vinogradov Institute of Geochemistry of Russia Academy of Science). The measured concentrations of $\mathrm{Ca}, \mathrm{Cd}, \mathrm{Cu}, \mathrm{Fe}, \mathrm{Mn}, \mathrm{Ni}, \mathrm{Pb}, \mathrm{Rb}, \mathrm{Sr}$, and $\mathrm{Zn}$ were within recommended values. In addition, blanks were measured alongside the decomposition and analysis of the samples.

\subsection{Data Processing and Statistical Analysis}

Statistical processing of data included the calculation of these descriptive statistics: mean content, standard deviation, minimum and maximum content, median, variance, and coefficient of variation $(p \leq 0.05)$. The Pearson and Kolmogorov criterions were applied to test the hypothesis of normal distribution of the elements in the sample. For normal distribution, the Pearson correlation coefficients were used to characterize the ratio of two chemical elements. Different pollution sources were identified and characterized with the help of multivariate statistics (factor analysis). Principal component analysis was used. All statistical calculations were carried out with MS Excel software.

We also used QGIS 2.6.1 Brighton software to generate spatial distribution maps. For spatial distribution mapping the IDW (inverse distance weighting) method within QGIS 2.18 (Interpolation module) software package was applied. Given a small number of points, no RMSPE (root-mean-square "prediction" error) was done. The number of columns and rows was $500 \times 500$; the distance coefficient was 1. Opting for spatial distribution mapping instead of mere point mapping is justified by the key factors responsible for heavy metal distribution in the Kaliningrad region. For the region of strong cyclonic activity, with a high frequency of westerly air-mass trajectories, atmospheric transport is of great importance. In winter, the western and south-western directions of atmospheric transport prevail, while the summer mainly enjoys the north-western and southern wind currents. Western and southern cyclones causing rainy weather contribute to the deposition of pollutants into the region's territory. Airborne transport with deposition plays a dominant role, which led us to prefer visualizing the surface distribution in lichens using a continuous (interpolated) spatial distribution rather than 
individual data points [30]. The interpolation method of mapping provides a good visualization for relative metal accumulation, but not of actual absolute metal deposition on ecosystems.

\section{Results and Discussion}

Concentrations of such elements as iron, manganese, zinc, nickel, strontium, rubidium, and calcium were determined in the lichen samples collected across the study area, whereas cadmium, lead, copper, and silver concentrations were determined only in the lichens of the Sambian peninsula. Tables 1 and 2 show the results of the descriptive statistical analysis of heavy metal concentrations in the samples.

Table 1. Element concentrations in the H. physodes thallus in the Kaliningrad region, $\mu \mathrm{g} / \mathrm{g}$ DW.

\begin{tabular}{cccccccc}
\hline Metal & Mean & SD & SE & CV, \% & Median & Max & Min \\
\hline $\mathrm{Fe}$ & 446 & 183 & 33 & 41 & 399 & 1135 & 180 \\
$\mathrm{Mn}$ & 200 & 135 & 25 & 72 & 187 & 455 & 33 \\
$\mathrm{Zn}$ & 83 & 47 & 8 & 56 & 78 & 298 & 33 \\
$\mathrm{Ni}$ & 1.30 & 0.63 & 0.11 & 56 & 1.30 & 2.43 & 0.013 \\
$\mathrm{Sr}$ & 10.1 & 4.79 & 0.92 & 47 & 8.96 & 18.6 & 4.45 \\
$\mathrm{Rb}$ & 9.74 & 4.59 & 0.82 & 47 & 10.5 & 19.9 & 1.28 \\
$\mathrm{Ca}$ & 1203 & 817 & 140 & 68 & 980 & 2995 & 219 \\
\hline
\end{tabular}

Table 2. Concentrations of trace elements in the H. physodes thallus, the Sambian peninsula, $\mu \mathrm{g} / \mathrm{g}$ DW.

\begin{tabular}{cccccccc}
\hline Metal & Mean & SD & SE & CV, \% & Median & Max & Min \\
\hline $\mathrm{Ag}$ & 0.051 & 0.024 & 0.009 & 47 & 0.040 & 0.095 & 0.032 \\
$\mathrm{Cd}$ & 0.194 & 0.040 & 0.016 & 21 & 0.185 & 0.263 & 0.146 \\
$\mathrm{~Pb}$ & 6.57 & 2.36 & 0.96 & 36 & 7.15 & 9.03 & 3.50 \\
$\mathrm{Cu}$ & 7.91 & 1.21 & 0.49 & 15 & 7.83 & 9.94 & 6.69 \\
$\mathrm{Mn}$ & 313 & 253 & 103 & 81 & 259 & 664 & 74.2 \\
$\mathrm{Ni}$ & 1.64 & 0.549 & 0.225 & 34 & 1.611 & 2.43 & 0.941 \\
$\mathrm{Zn}$ & 79.5 & 22.7 & 9.26 & 29 & 87.7 & 100 & 45.6 \\
$\mathrm{Sr}$ & 15.0 & 10.3 & 4.22 & 69 & 10.7 & 31.5 & 6.38 \\
$\mathrm{Rb}$ & 12.2 & 5.59 & 2.28 & 45.8 & 10.9 & 22.6 & 5.69 \\
$\mathrm{Fe}$ & 610 & 279 & 114 & 45.7 & 526 & 1135 & 339 \\
$\mathrm{Ca}$ & 1253 & 0.855 & 0.349 & 68 & 1118 & 2684 & 375 \\
\hline
\end{tabular}

The results of chemical analysis were used to draw maps of element distribution in lichens. The prevailing SW winds would appear to determine the element distribution in the lichens of the Kaliningrad region. The study areas stretched from west and south-west to northeast. Higher concentrations of such trace elements as cadmium, nickel, iron, copper, and lead were observed on the Sambian peninsula and on the coast of the Vistula and Curonian Lagoons.

\subsection{The Spatial Distribution of Elements}

The iron concentration in the thalli of $H$. physodes varied from 180 to $1135 \mu \mathrm{g} / \mathrm{g}$ DW. The maximum concentration was observed in the area stretching from the centre of the Sambian peninsula toward the Vistula Lagoon coast and the northern coast of the Baltic Sea. High iron levels were observed on the southern coast of the Curonian Lagoon lying below sea level. The coefficient of variation was below $50 \%$. Higher values of iron concentrations can be explained by such geological features [40] as carrstones and iron-manganese nodules. High iron levels in soils and water pose a serious challenge to the region. Iron concentrations in lichens decrease from south-west to northeast (Figure 2). 


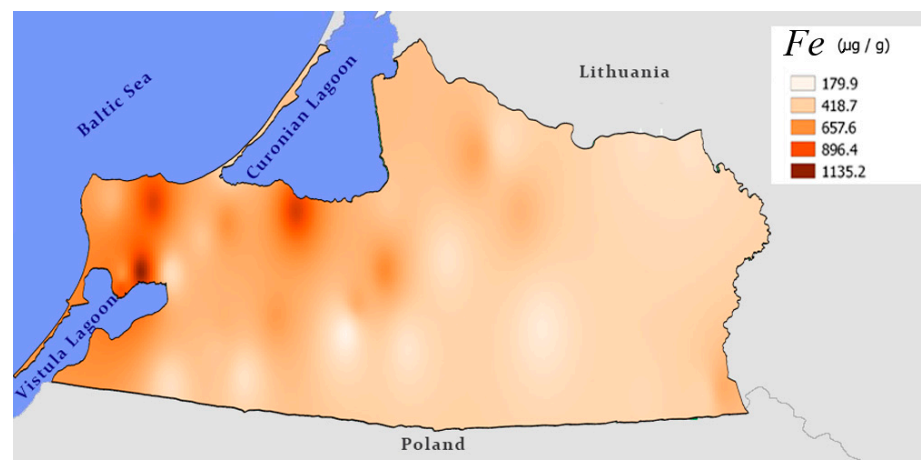

Figure 2. Distribution of iron in the thalli of H. physodes in the Kaliningrad region, 2010.

Nickel concentrations are estimated at hundreds or even thousands of mass units, depending on the time of exposure and the distance from the source of emission in the contaminated areas of nickel accumulation [25]. The concentrations of nickel in the Kaliningrad region varied from 0.013 to $2.43 \mu \mathrm{g} / \mathrm{g}$, coefficient of variation standing at $56 \%$. The pattern of nickel concentration distribution in the lichens of the Kaliningrad region did not differ from that of iron. The highest nickel concentrations in lichen thalli were observed in the western and southwestern parts of the region-on the Sambian peninsula and on the coasts of the Vistula and Curonian Lagoons (Figure 3).

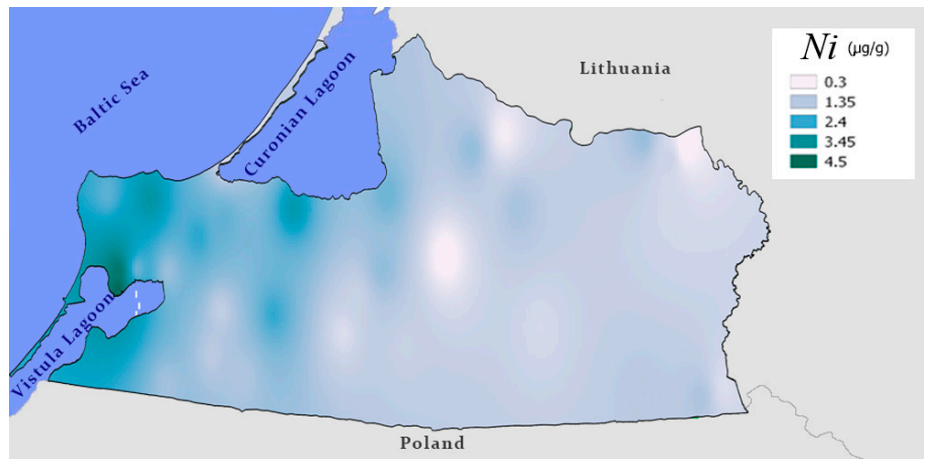

Figure 3. Distribution of nickel in the thalli of H. physodes in the Kaliningrad region, 2010.

The average manganese concentration is $200 \mu \mathrm{g} / \mathrm{g}$ DW; the coefficient of variation is $72 \%$, which reflects the heterogeneity of manganese concentration in the lichen thalli. The highest manganese levels (above $450 \mu \mathrm{g} / \mathrm{g}$ ) were found on the Sambian peninsula, on the coast of the Curonian Lagoon between the Rivers Deima and Pregolya, and in the region's southeast near Lake Vištytis (Figure 4).

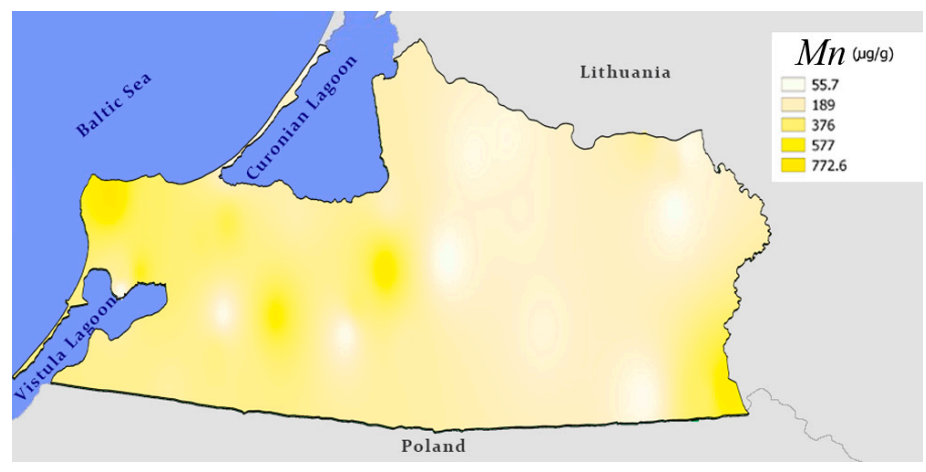

Figure 4. Distribution of manganese in the thalli of H. physodes in the Kaliningrad region, 2010. 
The concentration of zinc in lichens changed over a wide range-from 33 to $298 \mu \mathrm{g} / \mathrm{g}$, with the coefficient of variation at $56 \%$. The highest zinc concentrations were found in the northern part of the region in the River Neman valley (Figure 5).

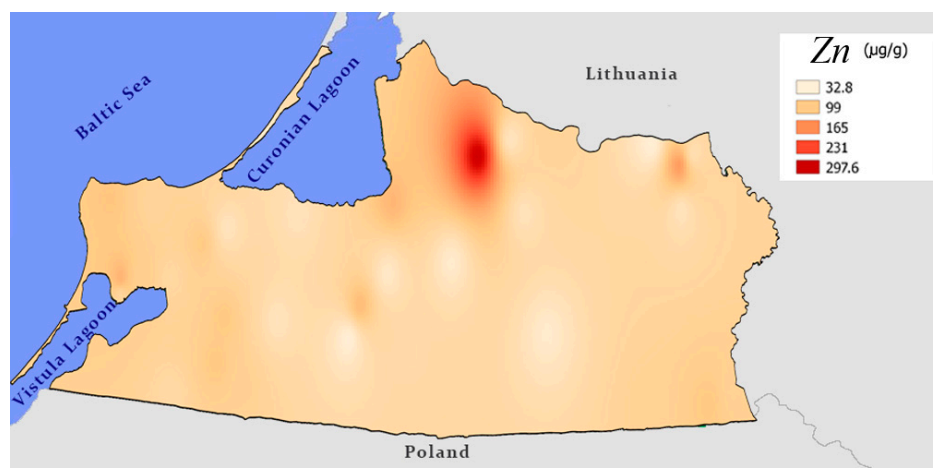

Figure 5. Distribution of zinc in the thalli of H. physodes in the Kaliningrad region, 2010.

Strontium is transferred from atmospheric air to water and soils [40]. The corresponding coefficient of variation was below $50 \%$. The concentrations of strontium in $H$. physodes differed slightly across the Kaliningrad region, ranging from 4.45 to $18.6 \mu \mathrm{g} / \mathrm{g}$. The maximum concentration was observed on the Sambian peninsula and in the River Pregolya valley. The biochemical properties of strontium are similar to those of calcium. Calcium concentrations ranged from 219 to $2995 \mu \mathrm{g} / \mathrm{g}$ (Figure 6). Elevated levels of strontium are usually human-caused (Figure 7).

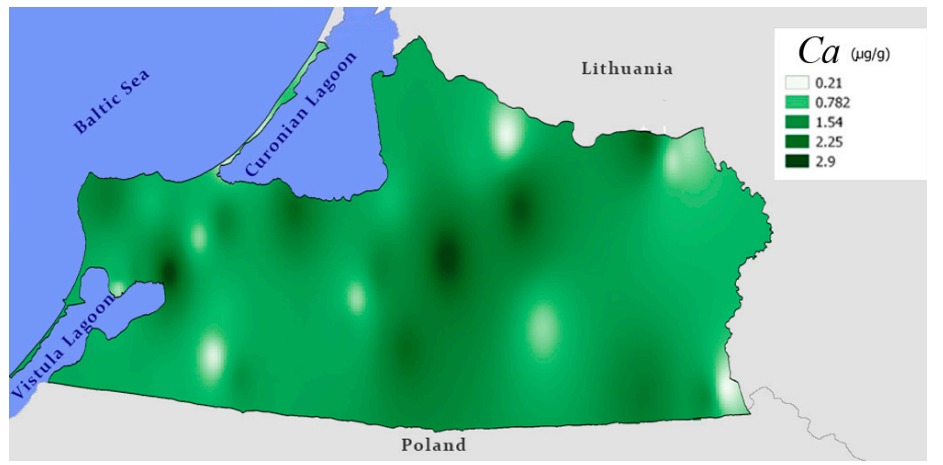

Figure 6. Distribution of calcium in the thalli of H. physodes in the Kaliningrad region, 2010.

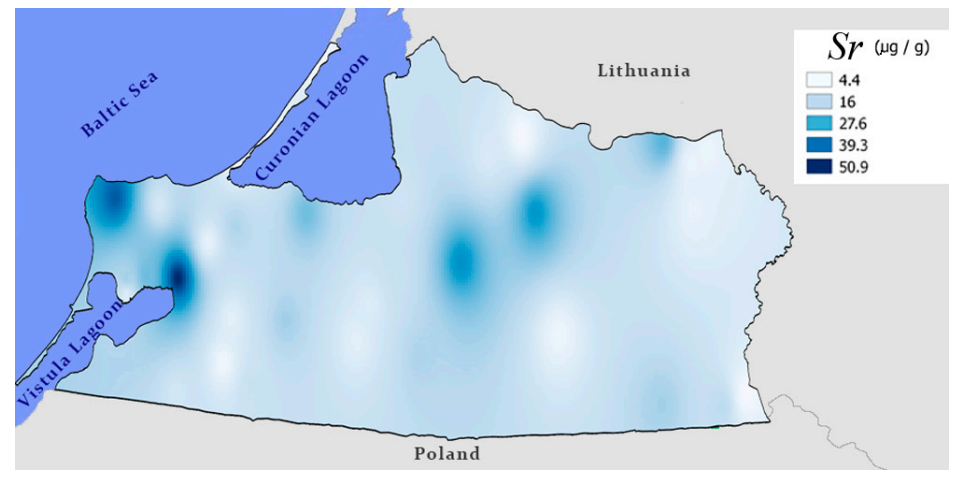

Figure 7. Distribution of strontium in the thalli of $H$. physodes in the Kaliningrad region, 2010.

Similar to the other monovalent cations, rubidium is absorbed by plants [41]. Rubidium can replace potassium in plants cells. The maximum concentrations of rubidium in H. physodes $(19.9 \mu \mathrm{g} / \mathrm{g})$ 
were found in the west of the region-on the Sambian peninsula and the northern coast of the Vistula Lagoon (Figure 8). The coefficient of variation was $47 \%$. The average and median values were equal.

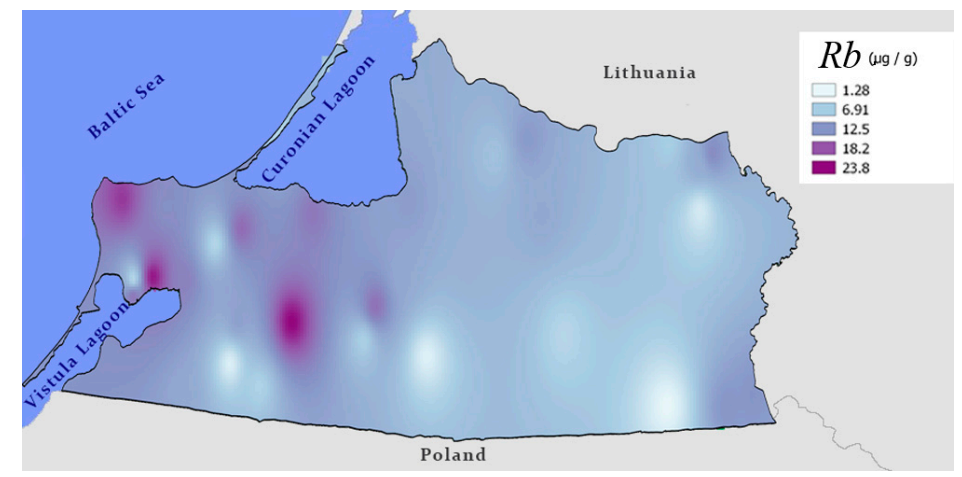

Figure 8. Distribution of rubidium in the thalli of H. physodes in the Kaliningrad region, 2010.

The average copper concentration in the lichen H. physodes was $7.91 \mu \mathrm{g} / \mathrm{g}$, with the lowest coefficient of variation. Sampling homogeneity was confirmed. The maximum copper concentration was $9.94 \mu \mathrm{g} / \mathrm{g}$.

The average concentration of lead was estimated at $6.57 \mu \mathrm{g} / \mathrm{g}$. The samples were homogeneous, and the coefficient of variation standing at $36 \%$. High lead levels were found in lichens in the western and central part of the Sambian peninsula.

The coefficient of variation of cadmium concentration in lichens on the Sambian peninsula was $21 \%$. The samples were homogeneous. The maximum level of $0.263 \mu \mathrm{g} / \mathrm{g}$ was observed in the northwest of the Sambian peninsula.

The average silver content in lichens was estimated at $0.051 \mathrm{mg} / \mathrm{g}$. The coefficient of variation was $47 \%$, which is indicative a relatively high heterogeneity of silver accumulation in lichens in different parts the Sambian Peninsula. The maximum silver concentrations in thalli $(0.095 \mu \mathrm{g} / \mathrm{g})$ were found in the north of Kaliningrad.

By concentrations in lichen samples, the elements were ranked as follows: $\mathrm{Ca}>\mathrm{Fe}>\mathrm{Mn}>\mathrm{Zn}>$ $\mathrm{Sr}>\mathrm{Rb}>\mathrm{Cu}>\mathrm{Pb}>\mathrm{Ni}>\mathrm{Cd}>\mathrm{Ag}$. Most elements exhibited lognormal or close to normal distribution $(p>0.05)$, which is characteristic of the lithogenic origin of crustal elements and is reflected in the atmospheric deposition from windblown soil dust. So, for a small spread and average median value, we can judge normal distribution of $\mathrm{Rb}, \mathrm{Mn}, \mathrm{Ca}, \mathrm{Cu}, \mathrm{Zn}, \mathrm{Fe}, \mathrm{Ni}, \mathrm{Sr}$, and $\mathrm{Ag}$, and close to normal for $\mathrm{Cd}$ and $\mathrm{Pb}$. Distribution of $\mathrm{Cd}$ and $\mathrm{Pb}$ in lichen samples was influenced by other anthropogenic factors.

To evaluate the degree of contamination in the Kaliningrad region, the contamination factor (CF) $[21,42]$ was calculated according to the following formula:

$$
\mathrm{CF}=\frac{\mathrm{C}_{\mathrm{i}}}{\mathrm{C}_{\mathrm{b}}}
$$

where $C_{i}$ is the concentration of elements in lichens in the study area and $C_{b}$ the concentration of the same elements in the control areas. The Arctic ( $\mathrm{Sr}$ and $\mathrm{Rb}$ ) and Northern Canada (other elements) were chosen as control [43,44] (Table 3).

For interpreting the results, six categories corresponding to $\mathrm{CF}$ values were introduced. CF 1 means no contamination (category C1), 1-2 suspected contamination (C2), 2-3.5 slight contamination (C3), 3.5-8 moderate contamination (C4), 8-27 severe contamination (C5), and 27 extreme contamination levels (C6) [45].

Thus, the level of trace element air pollution in the Kaliningrad region was estimated at C2, with the exception of Fe and $\mathrm{Rb}$. However, in the western part of the Sambian peninsula, where the factors 
are higher than in the other areas, it was estimated at C3. The concentrations of lead and iron also considerably exceed control values.

Table 3. Contamination factor in the Kaliningrad region.

\begin{tabular}{ccccc}
\hline \multirow{2}{*}{ Metal } & \multicolumn{2}{c}{ Sambian Peninsula } & \multicolumn{2}{c}{ Kaliningrad Region } \\
\cline { 2 - 5 } & CF & Classification & CF & Classification \\
\hline $\mathrm{Pb}$ & 22 & $\mathrm{C} 5$ & - & - \\
$\mathrm{Cd}$ & 3.1 & $\mathrm{C} 3$ & - & - \\
$\mathrm{Cu}$ & 2.1 & $\mathrm{C} 3$ & - & - \\
$\mathrm{Ni}$ & 2.0 & $\mathrm{C} 3$ & 1.6 & $\mathrm{C} 2$ \\
$\mathrm{Zn}$ & 2.2 & $\mathrm{C} 3$ & 1.9 & $\mathrm{C} 2$ \\
$\mathrm{Fe}$ & 9.7 & $\mathrm{C} 5$ & 7.4 & $\mathrm{C} 4$ \\
$\mathrm{Ca}$ & 1.5 & $\mathrm{C} 2$ & 1.2 & $\mathrm{C} 2$ \\
$\mathrm{Mn}$ & 2.0 & $\mathrm{C} 3$ & 1.4 & $\mathrm{C} 2$ \\
$\mathrm{Sr}$ & 2.3 & $\mathrm{C} 3$ & 1.9 & $\mathrm{C} 2$ \\
$\mathrm{Rb}$ & 2.7 & $\mathrm{C} 3$ & 2.6 & $\mathrm{C} 3$ \\
\hline
\end{tabular}

\subsection{The Principle Component Factor Analysis}

To identify the relationships (linear dependence) between the elements in lichen samples, a correlation matrix was calculated (Table 4). It shows slight correlations $<0.3-0.4$; high correlations- $0.5-0.75$, and significant correlations $>0.75$ [46].

Table 4. Pearson correlation coefficient $\left(n=35 ;{ }^{* *} p\right.$ value $<0.01 ;{ }^{*} p$ value $\left.<0.05\right)$.

\begin{tabular}{ccccccccccc}
\hline Metal & $\mathbf{M n}$ & $\mathbf{N i}$ & $\mathbf{Z n}$ & $\mathbf{S r}$ & $\mathbf{R b}$ & $\mathbf{F e}$ & $\mathbf{C a}$ & $\mathbf{A g}$ & $\mathbf{C d}$ & $\mathbf{P b}$ \\
\hline $\mathrm{Mn}$ & 1.00 & - & - & - & - & - & - & - & - & - \\
$\mathrm{Ni}$ & $0.67^{*}$ & 1.00 & - & - & - & - & - & - & - & - \\
$\mathrm{Zn}$ & -0.38 & -0.20 & 1.00 & - & - & - & - & - & - & - \\
$\mathrm{Sr}$ & 0.13 & 0.19 & -0.43 & 1.00 & - & - & - & - & - & - \\
$\mathrm{Rb}$ & 0.28 & 0.10 & -0.12 & $0.42^{*}$ & 1.00 & - & - & - & - & - \\
$\mathrm{Fe}$ & $0.65^{*}$ & $0.46^{*}$ & -0.10 & 0.49 & $0.82^{* *}$ & 1.00 & - & - & - & - \\
$\mathrm{Ca}$ & 0.17 & 0.12 & -0.62 & $0.91^{* *}$ & 0.16 & 0.30 & 1.00 & - & - & - \\
$\mathrm{Ag}$ & -0.47 & -0.01 & 0.19 & -0.08 & -0.24 & -0.21 & 0.01 & 1.00 & - & - \\
$\mathrm{Cd}$ & 0.42 & -0.10 & 0.04 & 0.25 & -0.05 & 0.23 & 0.30 & -0.64 & 1.00 & - \\
$\mathrm{Pb}$ & 0.33 & -0.22 & 0.29 & -0.17 & 0.07 & 0.34 & -0.05 & -0.02 & $0.56^{*}$ & 1.00 \\
$\mathrm{Cu}$ & -0.13 & 0.24 & 0.45 & -0.64 & -0.75 & -0.59 & -0.60 & 0.09 & -0.12 & -0.22 \\
\hline
\end{tabular}

Significant positive correlations $\left(R^{2}>0.75, p=0.01\right)$ were found between $\mathrm{Ca}$ and $\mathrm{Sr}(0.91)$, Fe and $\mathrm{Rb}(0.82)$ in lichens samples. High positive correlation $\left(R^{2}>0.5, p=0.05\right)$ were found between $\mathrm{Mn}$ and $\mathrm{Ni}(0.67), \mathrm{Fe}$ and $\mathrm{Mn}(0.65), \mathrm{Cd}$ and $\mathrm{Pb}(0.56)$. Week positive correlation $\left(R^{2}<0.5, p=0.05\right)$ were found between $\mathrm{Ni}$ and $\mathrm{Fe}(0.46)$ and $\mathrm{Rb}$ and $\mathrm{Sr}(0.42)$. This may be indicative of a common source of contamination. There are four major sources of trace elements, which correspond to the geographic and climatic features of the region - the atmospheric transport from the sea (marine factor), windblown dust from local soils (soil factor), the transport of soluble compounds from atmospheric precipitation, and vascular plant root uptake from the soil and the subsequent transfer to lichens (vegetative factor).

To aid interpretation of the findings, a factor analysis was carried out, whose results allowed us to derive four main factors to be further interpreted as source categories contributing to element concentrations at the sampling sites. Examining the factor profiles, i.e., the loading of elements and other variables after varimax rotation, identified the source categories. The main criterion for selecting the number of optimal factors and models of major source detection is that eigenvalues must be greater than 1 [47].

The results of factor analysis, the loading values of each element and the association of elements with the factors (omitting values $<0.2$ ) are shown in Table 5. 
Table 5. The results of the flame atomic FA analysis of the correlation matrix.

\begin{tabular}{ccccc}
\hline Variable & Factor $\mathbf{1}$ & Factor 2 & Factor 3 & Factor 4 \\
\hline $\mathrm{Mn}$ & & 0.266 & 0.518 & 0.766 \\
$\mathrm{Ni}$ & & & & 0.946 \\
$\mathrm{Zn}$ & -0.791 & & & -0.271 \\
$\mathrm{Sr}$ & 0.833 & 0.379 & & \\
$\mathrm{Rb}$ & & 0.917 & & 0.407 \\
$\mathrm{Fe}$ & 0.867 & 0.221 & -0.238 \\
$\mathrm{Ca}$ & & & & - \\
$\mathrm{Ag}$ & & & 0.695 & -0.223 \\
$\mathrm{Cd}$ & -0.358 & 0.373 & 0.640 & 0.276 \\
$\mathrm{~Pb}$ & -0.539 & -0.755 & & 13.5 \\
$\mathrm{Cu}$ & 36.2 & 19.4 & 15.6 & 1.9 \\
Extraction sums of & & & & \\
squared loadings & 24.2 & 23.2 & 19.8 & \\
Rotation sums of & & & & \\
squared loadings & & &
\end{tabular}

Factor 1 is the strongest, accounting for $36.2 \%$ of the total variance. It is influenced by high positive loadings of strontium andcalcium and the negative ones of zinc and copper. Strontium is isomorphic with calcium in geochemical processes. Thus, factor 1 may be caused by marine aerosols.

Factor 2 is the second strongest factor accounting for $19.4 \%$ of the total variance. It is influenced by the loadings of rubidium, iron, strontium, and by negative ones of copper. Most likely, the origin of these metals is natural-for instance, uptake by tree root systems and the subsequent absorption by lichens.

Factor 3 accounts for $15.6 \%$ of the total variance. This factor is associated with such elements as cadmium and lead, which are typically derived from atmospheric pollution deposition. Silver was anti-correlated with $\mathrm{Cd}$ and $\mathrm{Pb}$, which manifests in its negative loading on factor 3 .

Factor 4 , which accounts for $13.5 \%$ of the total variance, is connected with the positive loadings of $\mathrm{Mn}, \mathrm{Ni}$, and $\mathrm{Fe}$. This factor is associated with a typical crustal composition and is probably connected with wind-blown dust deposition on lichens thalli.

\section{Conclusions}

The average concentrations of metals in the epiphytic lichen $H$. physodes in the Kaliningrad region corresponded to those of trace elements in the control areas. However, the lichens of the Sambian peninsula accumulate trace elements more intensively. Given the local peculiarities of atmospheric circulation and the microclimatic variability of meteorological indicators under the influence of the Baltic Sea, three types of climate are distinguished: marine, transitional, and continental [30]. They differ in the amounts of precipitation and wind strengths. These factors affect the distribution of microelements in the Kaliningrad region and contribute to their transfer and deposition along with atmospheric precipitation in the northeasterly and easterly directions. Lichens accumulate microelements more intensively in the west of the Kaliningrad region than in its continental part, which is also due not only to a higher level of urbanization of the territory, but also to the region's climatic features.

The observed levels in the Kaliningrad region, particularly of lead and cadmium, are likely affected by anthropogenic emissions, but it is possible that the composition of trace elements in the lichens of the Sambian peninsula is affected not only by local pollution sources, such as vehicles, thermal energy facilities, and ports, but also by the transboundary traffic and sea spray.

The present study is the first step toward lichen-based air contamination monitoring in the Kaliningrad region. It can serve as groundwork for further research. Continued studies are planned into trace element concentrations in the lichen H. physodes and to establish spatial features and the temporal dynamics of air pollution in the Kaliningrad region. 
Author Contributions: Yulia Koroleva collected the lichens samples, performed the chemical experiments, analyzed the data and wrote the paper. Vladimir Revunkov created the maps.

Conflicts of Interest: The authors declare no conflict of interest.

\section{References}

1. Tyler, G. Uptake, retention, and toxicity of heavy metals in lichens. Water Air Soil Pollut. 1989, 47, $321-333$. [CrossRef]

2. Garty, J.; Karary, Y.; Harel, J.; Lurie, S. Temporal and spatial fluctuations of ethylene production and concentrations of sulfur, sodium, chlorine and iron on/in the thallus cortex in thelichen Ramalina duriaei (De Not.) Bagl. Environ. Exp. Bot. 1993, 33, 553-563. [CrossRef]

3. Garty, J. Biomonitoring atmospheric heavy metals with lichens: Theory and application. Crit. Rev. Plant. Sci. 2001, 20, 309-371. [CrossRef]

4. Chettri, M.K.; Sawidis, T.; Karataglis, S. Lichens as a tool for biogeochemical prospecting. Ecotoxicol. Environ. Saf. 1997, 38, 322-335. [CrossRef] [PubMed]

5. Nimis, P.L.; Andreussi, S.; Pittao, E. The performance of two lichen species as bioaccumulators of trace metals. Sci. Total Environ. 2001, 275, 43-51. [CrossRef]

6. Bergamaschi, L.; Rizzio, E.; Giaveri, G.; Loppi, S.; Gallorini, M. Comparison between the accumulation capacity of four lichen species transplanted to a urban site. Environ. Pollut. 2007, 148, 468-476. [CrossRef] [PubMed]

7. Balabanova, B.; Stafilov, T.; Šajn, R.; Baèeva, K. Characterisation of Heavy Metals in Lichen Species Hypogymnia physodes and Evernia prunastri due to Biomonitoring of Air Pollution in the Vicinity of Copper Mine. Int. J. Environ. Res. 2012, 6, 779-794.

8. Tretiach, M.; Baruffo, L. Effects of $\mathrm{H}_{2} \mathrm{~S}$ on $\mathrm{CO}_{2}$ gas exchanges and growth rates of the epiphytic lichen Parmelia sulcata Taylor. Symbiosis 2001, 31, 35-46.

9. Adamo, P.; Crisafulli, P.; Giordano, S.; Minganti, V.; Modenesi, P.; Monaci, F.; Pittao, E.; Tretiach, M.; Bargagli, R. Lichen and moss bags as monitoring devices in urban areas. Part II: Trace element content in living and dead biomonitors and comparison with synthetic materials. Environ. Pollut. 2007, 146, 392-399. [CrossRef] [PubMed]

10. Chiarenzelli, J.R.; Aspler, L.B.; Ozarko, D.L.; Hall, G.E.; Powis, K.B.; Donaldson, J.A. Heavy metals in lichens, southern District of Keewatin, Northwest Territories, Canada. Chemosphere 1997, 35, 1329-1341. [CrossRef]

11. Osyczka, P.; Rola, K. Response of the lichen Cladonia rei Schaer. to strong heavy metal contamination of the substrate. Environ. Sci. Pollut. Res. 2013, 20, 5076-5084. [CrossRef] [PubMed]

12. Rola, K.; Osyczka, P. Cryptogamic community structure as a bioindicator of soil condition along a pollution gradient. Environ. Monit. Assess. 2014, 186, 5897-5910. [CrossRef] [PubMed]

13. Rola, K.; Osyczka, P.; Nobis, M.; Drozd, P. How do soil factors determine vegetation structure and species richness in post-smelting dumps? Ecol. Eng. 2015, 75, 332-342. [CrossRef]

14. Bačkor, M.; Loppi, S. Interactions of lichens with heavy metals. Biol. Plantarum. 2009, 53, 214-222. [CrossRef]

15. Garty, J.; Galun, M.; Kessel, M. Localization of heavy metals and other elements accumulated in the lichen thallus. New Phytol. 1979, 82, 159-168. [CrossRef]

16. Goyal, R.; Seaward, M.R.D. Metal uptake in terricolous lichens I. Metal localization within the thallus. New Phytol. 1981, 89, 631-645. [CrossRef]

17. Sarret, G.; Manceau, A.; Cuny, D.; van Halowyn, C.; Deruelle, S.; Hazemann, J.L.; Soldo, Y.; Eybert-Bérard, L.; Menthonnex, J.J. Mechanisms of lichen resistance to metallic pollution. Environ. Sci. Technol. 1998, 32, 3325-3330. [CrossRef]

18. Basile, A.; Sorbo, S.; Aprile, G.; Conte, B.; Castaldo Cobianchi, R. Comparison of the heavy metal bioaccumulation capacity of an epiphytic moss and an epiphytic lichen. Environ. Pollut. 2008, 151, 401-407. [CrossRef] [PubMed]

19. Purvis, O.W.; Pawlik-Skowrońska, B. Lichens and metals. In Stress in Yeasts and Filamentous Fungi; Avery, S.V., Stratford, M., van West, P., Eds.; Elsevier: Amsterdam, The Netherlands, 2008; pp. 175-200.

20. Bajpai, R.; Upreti, D.K. Accumulation and toxic effect of arsenic and other heavy metals in a contaminated area of West Bengal, India, in the lichen Pyxine cocoes (Sw.) Nyl. Ecotoxicol. Environ. Saf. 2012, 83, 63-70. [CrossRef] [PubMed] 
21. Conti, M.E.; Cecchetti, G. Biological monitoring: Lichens as bioindicators of air pollution assessment-A review. Environ. Pollut. 2001, 114, 471-492. [CrossRef]

22. Poikolainen, J. Mosses, Epiphytic Lichens and Tree Bark as Biomonitors for Air Pollutants—Specifically for Heavy Metals in Regional Surveys; Oulu University Press: Oulu, Finland, 2004; ISBN 9514274792.

23. Cuny, D.; Denayer, F.O.; de Foucault, B.; Schumacker, R.; Colein, P.; van Haluwyn, C. Patterns of metal soil contamination and changes in terrestrial cryptogamic communities. Environ. Pollut. 2004, 129, $289-297$. [CrossRef] [PubMed]

24. Pirintsos, S.A.; Matsi, T.; Vokou, D.; Gaggi, C.; Loppi, S. Vertical distribution patterns of trace elements in an urban environment as reflected by their accumulation in lichen transplants. J. Atmos. Chem. 2006, 54, 121-131. [CrossRef]

25. Nieminen, T.M.; Ukonmaanaho, L.; Rausch, N.; Shotyk, W. Biogeochemistry of Nickel and Its Release into the Environment. Met. Ions Life Sci. 2007, 2, 1-30.

26. Klimek, B.; Tarasek, A.; Hajduk, J. Trace Element Concentrations in Lichens Collected in the Beskidy Mountains, the Outer Western Carpathians. Bull. Environ. Contam. Toxicol. 2015, 94, 532-536. [CrossRef] [PubMed]

27. Boonpragob, K.; Nash, T.H. Seasonal variation of elemental status in the lichen Ramalina menziesii Tayl. from 2 sites in southern California-Evidence for dry deposition accumulation. Environ. Exp. Bot. 1990, 30, 415-428. [CrossRef]

28. Walther, D.A.; Ramelov, G.J.; Beck, J.N.; Young, J.C.; Callahan, J.D.; Marcon, M.F. Temporal changes in metal levels of the lichen Parmotrema praesorediosum and Ramalina stenospora, southwest Louisiana. Water Air Soil Pollut. 1990, 53, 189-200. [CrossRef]

29. Cuny, D.; Davranche, L.; Thomas, P.; Kempa, M.; van Haluwyn, C. Spatial and temporal variations of trace element contents in Xanthoria parietina thalli collected in a highly industrialized area in northern France as an element for a future epidemiological study. J. Atmos. Chem. 2004, 49, 391-401. [CrossRef]

30. Barinova, G.M. Kaliningrad Region; Climate; Publishing House “Amber Tale”: Kaliningrad, Russia, 2002.

31. Kucheryavy, P.P.; Fedorov, G.M. Geography of the Kaliningrad Region; Kaliningrad Book Publishing House: Kaliningrad, Russia, 1989.

32. Král, R.; Kryžová, L.; Liška, J. Background concentrations of lead and cadmium in the lichen Hypogymnia physodes at different altitudes. Sci. Total Environ. 1989, 84, 201-209. [CrossRef]

33. Paul, A.; Hauck, M.; Langenfeld-Heyser, R. Ultrastructural changes in soredia of the epiphytic lichen Hypogymnia physodes cultivated with manganese. Environ. Exp. Bot. 2004, 52, 139-147. [CrossRef]

34. Hauck, M.; Huneck, S. Lichen substances affect metal adsorption in Hypogymnia physodes. J. Chem. Ecol. 2007, 33, 219-223. [CrossRef] [PubMed]

35. Mikhailova, I.N.; Sharunova, I.P. Dynamics of heavy metal accumulation in thalli of the epiphytic lichen Hypogymnia physodes. Russ. J. Ecol. 2008, 39, 346-352. [CrossRef]

36. Koroleva, Y. Use of mosses Hylocomium splendens and Pleurozium schreberi for an estimation of absolute values of atmospheric losses of heavy metals in Kaliningrad areas. Vestnik IKBFU 2006, 7, 29-34.

37. Koroleva, Y.; Pukhlova, I. New data on heavy metal bioconcentration on the territory of the Baltic region. Vestnik IKBFU 2012, 12, 99-106.

38. Koroleva, Y.; Vakhranyova, O.; Okhrimenko, M. Accumulation of Trace Elements by Wild Mushrooms in West Part of Russia (South-Eastern Baltic). Available online: http://lodel.irevues.inist.fr/pollutionatmospherique/index.php?id=4989 (accessed on 15 February 2017).

39. Steins, E. A critical evaluation of the use of naturally growing moss to monitor the deposition of atmospheric metals. Sci. Tot. Environ. 1995, 160, 243-249. [CrossRef]

40. Vinogradov, A.R. Average contents of chemical elements in the principal type of igneous rocks of the Earth's crust. Geochemistry 1962, 7, 555-571.

41. Kabata-Pendias, A.; Szteke, B. Trace Elements in Abiotic and Biotic Environments; MIR: Moscow, Russia, 1989.

42. Carballeira, A.; Carral, E.; Puente, X.; Villares, R. Regional-scale monitoring of coastal contamination. Nutrients and heavy metals in estuarine sediments and organisms on the coast of Galicia (NW Spain). Environ. Pollut. 2000, 13, 534-572. [CrossRef]

43. Chiarenzelli, J.; Aspler, L.; Dunn, C.; Cousens, B.; Ozarko, D.; Powis, K. Multi-element and rare earth element composition of lichens, mosses, and vascular plants from the Central Barrenlands, Nunavut, Canada. Appl. Geochem. 2001, 16, 245-270. [CrossRef] 
44. Darnajoux, R.; Lutzoni, F.; Miadlikowska, J.; Bellenger, J.-P. Determination of elemental baseline using peltigeralean lichens from Northeastern Canada (Québec): Initial data collection for long term monitoring of the impact of global climate change on boreal and subarctic area in Canada. Sci. Total Environ. 2015, 533, 1-7. [CrossRef] [PubMed]

45. Fernández, J.A.; Carballeira, A. Evaluation of contamination, by different elements, in terrestrial mosses. Arch. Environ. Contam. Toxicol. 2001, 40, 461-468. [PubMed]

46. Nimis, P.L.; Scheidegger, C.; Wolseley, P.A. (Eds.) Monitoring Lichens-Monitoring with Lichens; Kluwer: Dordrecht, The Netherlands, 2002; pp. 295-299.

47. Berg, T.; Røyset, O.; Steinnes, E.; Vadset, M. Atmospheric Trace Element Deposition: Principal Component Analysis of ICP-MS Data from Moss Samples. Environ. Pollut. 1995, 88, 67-77. [CrossRef]

(C) 2017 by the authors. Licensee MDPI, Basel, Switzerland. This article is an open access article distributed under the terms and conditions of the Creative Commons Attribution (CC BY) license (http:/ / creativecommons.org/licenses/by/4.0/). 